\title{
Comparative Evaluation of in vitro Cellular Uptake and Antiproliferative Potential of Different Extracts of Orthosiphon pallidus Royle
}

\author{
Mukesh K. Singh ${ }^{1 *}$, Hemant Dhongade ${ }^{1}$, and Dulal Krishna Tripathi ${ }^{2}$ \\ ${ }^{1}$ Shri Rawatpura Sarkar Institute of Pharmacy, Kumhari, Durg, Chhattisgarh, INDIA. \\ ${ }^{2}$ Rungta College of Pharmaceutical Sciences and Research, Kohka, Road, Bhilai, Durg, Chhattisgarh, INDIA.
}

\begin{abstract}
Objective: Evaluation of the cytotoxic effect of different extracts of Orthosiphon pallidus Royle on MCF-7 cell lines, comparatively. Materials and Methods: The breast cell line MCF-7 was cultured in DMEM medium containing fetal bovine serum \& antibiotics. The cells were exposed to different doses of all the ethanolic, aqueous and hydroalcoholic extracts and incubated for 24, 48 and 72 hrs respectively and further studied for MTT colorimetric test, SRB test, glutathione assay and cellular uptake assay. Results: The results showed hydroalcoholic extract had a dose and time-dependent anticancer effect on MCF-7 cancer cells after 72 hours $(P<0.05)$. The study revealed that Orthosiphon pallidus Royle could inhibit the growth of cancerous cells. Conclusion: The ethanolic, aqueous and hydroalcoholic extracts of Orthosiphon pallidus Royle exhibited anticancer activity in a wide range in dose -dependent manner. The study concluded that Orthosiphon pallidus Royle shows cellular uptake and anti-proliferative activities.
\end{abstract}

Key words: Breast Cancer, Cytotoxic Effect, MCF-7 Cell Line, Fetal Bovine Serum, Glutathione's.

\section{INTRODUCTION}

Orthosiphon pallidus Royle (Laminaceae) is a medicinal herbaceous shrub widely distributed in South East Asia, and it is used for the treatment of different diseases like fever, hepatitis, edema, jaundice, and rheumatism. ${ }^{1}$ It is a perennial herb with a woody rootstock not aromatic. Stems are diffusely branched ascending vertical $10-35 \mathrm{~cm}$, slender, quadrangular, velvety or almost hairless. Leaves are ovate, $1-3.5 \times 1.2$, pale green, slightly fleshy, nearly entire to saw-toothed, gland-dotted, stalked, velvety, and almost hairless. Flower stalks are $2 \mathrm{~mm}$ in flower and up to $6 \mathrm{~mm}$ in fruit, velvety in the lower part, upper lobe ovate-circular. ${ }^{2}$ The current literature revealed nothing about the chemical investigation of Orthosiphon pallidus Royle except those reported by Regina. ${ }^{3}$ Indigenous studies on the plant stated the plant is highly rich in antioxidants and exhibits a huge plethora of pharmacological activities like anticancer, anti hepatotoxicity, antidiabetic, antiviral, nephroprotective, etc. ${ }^{4,5}$

Breast cancer is a disease, which hampers the mental and physical aspects of a human body specifically of women. The disease is a slow progressive in nature and useually manifested in later stages. ${ }^{6,7}$ In India, the incidence of breast cancer has become crucial. In a survey done by World Health Organization, women at the age group of 30-50 years are at a higher risk of developing breast cancer, worldwide. ${ }^{8,9}$ There are several reasons for developing breast cancer in women. However, the darker side of the crisis is that there is no prominent drug available today to treat the disease. The synthetic drugs available have major side effects, and the ultimate remedy remains the surgical removal of the breast, which also does not assure 100\% survival and quality of life. ${ }^{10-12}$ Herbal drugs or drugs derived
Submission Date: 19-12-2016; Revision Date: 31-03-2017; Accepted Date: 05-05-2017

DOI: 10.5530/ijper.51.4.106 Correspondence: Mr. Mukesh Kumar Singh, Shri Rawatpura Sarkar Institute of Pharmacy, Kumhari, Durg,

Chhattisgarh, INDIA

Phone: +91-9691699320, $+91-8109043251$ E-mail: mukeshbiotech09@ gmail.com

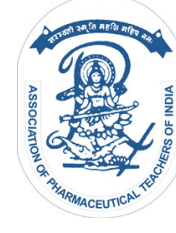

www.ijper.org 
from natural resources could serve as an alternative to the disease. Herbal extracts being antioxidant in nature they have the capacity to fight against the disease in a synergistic manner to reduce the adverse effects, the concurrence of pain, relapsing nature of disease as well as with the related complications. ${ }^{13-15}$ Hence, the present study was designed to identify a good candidate of herbal source for breast cancer. The objective of the present work was to perform a comparative evaluation of in vitro cellular uptake and antiproliferative potential of different extracts of Orthosiphon pallidus Royle.

\section{MATERIALS AND METHODS}

\section{Collection and identification of plant material}

The plants of Orthosiphon pallidus Royle were collected from local areas of Pratapgarh district, Uttar Pradesh, India. The plant was authenticated and identified by B. K. Shukla, Scientist-D, Botanical Survey of India, Central Regional Centre, Allahabad, Uttar Pradesh [Voucher Specimen No. BSI/CRC/ 2013/1286].

\section{Preparation of Orthosiphon pallidus Royle extracts (OPRE)}

The fresh whole plant was air dried and extracted with ethanol for ethanolic extract, water for aqueous extract and water and alcohol in a ratio of 50:50 for hydroalcoholic extract, using a Soxhlet extractor for $8 \mathrm{hrs}$ at $55-60{ }^{\circ} \mathrm{C}$. The supernatant was filtered through Whatman filter paper No.1 and concentrated under reduced pressure using vaccum at $44 \pm 1^{\circ} \mathrm{C}$ in a rotavapor (IKA ${ }^{\circledR}$ RB 10 ROTA EVAPORATOR, INDIA) followed by lyophilization (Thermo fisher, Germany \& Thermo Heto LL 3000). The lyophilized plant powder was stored at $22^{\circ} \mathrm{C}$.

\section{MTT assay chemicals}

MTT [\{3-(4, 5-dimethyl thiazol-2-yl)-5-diphenyltetrazolium bromide\}], FBS (fetal bovine serum) PBS (phosphate buffered saline) trypsin, EDTA and DMEM (Dulbecco's modified Eagle's medium), MEM (Minimal Essential Eagle's Medium) were obtained from Sigma Chemicals (St. Louis, Mo, USA). Glucose and antibiotics were obtained from Hi-Media Laboratories Ltd., Mumbai. DMSO (dimethyl sulfoxide) and propanol were purchased from E. Merck Ltd., Mumbai, INDIA. All other chemicals and solvent used were of the standard analytical grade.

\section{Sulforhodamine B assay chemicals}

Sulforhodamine B (SRB), FBS (fetal bovine serum), PBS (phosphate buffered saline) DMEM (Dulbecco's modified Eagle's medium) and trypsin were obtained from Sigma Chemicals (St. Louis, Mo, USA). EDTA, glucose, trichloroacetic acid (TCA), acetic acid, Tris and antibiotics were purchased from Sisco Research Laboratories (Kolkata, INDIA ). Dimethyl sulfoxide (DMSO) and propanol from E. Merck Ltd., Mumbai, INDIA, were used for the study. All other chemicals and solvent used were of the standard analytical grade.

\section{Cell line and culture medium}

Human breast cancer cells (MCF-7) cell line was used for cytotoxicity study. Stock cells of MCF-7 were cultured in DMEM. Medium was supplemented with $10 \%$ inactivated FBS, penicillin $(100 \mathrm{IU} / \mathrm{mL})$, streptomycin $(100 \mathrm{mg} / \mathrm{mL})$ and amphotericin $\mathrm{B}(5 \mathrm{mg} / \mathrm{mL})$ in an humidified atmosphere of $5 \% \mathrm{CO}_{2}$ at $37^{\circ} \mathrm{C}$ until confluent. ${ }^{16,17}$ The cells were dissociated with Trypsin Phosphate Versene Glucose (TPVG) solution (0.2\% trypsin, $0.02 \%$ EDTA, $0.05 \%$ glucose in PBS). The stock cultures were grown in $25 \mathrm{~cm}^{2}$ culture flasks and all experiments were carried out in 96 microtitre plates (I Mark ${ }^{\mathrm{TM}}$ Micro plate Absorbance Reader, BioRad, United States).

\section{Preparation of test solutions}

Test extracts and standard drug were separately dissolved in distilled DMSO for the cytotoxicity study. The volume was made up with DMEM supplemented with $2 \%$ inactivated FBS to obtain a stock solution of $1 \mathrm{mg} / \mathrm{mL}$ concentration and sterilized by filtration. Serial two-fold dilutions were prepared from this for carrying out cytotoxicity studies.

\section{In vitro anticancer activity of Orthosiphon pallidus Royle}

\section{MTT assay}

Human breast cancer cells (MCF-7) were cultured in RPMI-1641 media containing 10\% FBS, $100 \mu \mathrm{g} / \mathrm{mL}$ penicillin, and $100 \mu \mathrm{g} / \mathrm{mL}$ streptomycin in a humidified atmosphere with $5 \% \mathrm{CO}_{2}$ at $37^{\circ} \mathrm{C}$. Cells were plated in $100 \mu \mathrm{L}$ of media per well (8000 cells /well) in 96 well plates. After 48 hours when the cells reached $70-80 \%$ confluency, media was removed from the plate and washed with PBS once. Serum free media $(100 \mu \mathrm{L})$ was added to each well and kept for 12 hours at $37^{\circ} \mathrm{C}$ in an incubator (BB150 $\mathrm{CO}_{2}$ Incubator, Thermo Fischer, India) with $5 \% \mathrm{CO}_{2}$. Different dilutions of the extracts including standard drug were added in various concentration $(10,20,50,100 \mu \mathrm{g} / \mathrm{mL}$, dissolved in $0.1 \%$ DMSO) and incubated for 24 hours at $37^{\circ} \mathrm{C}$. MTT solution $(10 \mu \mathrm{L})$ of was added to each well (stock $1 \mathrm{mg} / \mathrm{mL}$ in PBS) after 24 hours. The plate was then wrapped in foil and incubated at $37^{\circ} \mathrm{C}$ for 4 hours. DMSO $(200 \mu \mathrm{L})$ was then added and kept on a shaker (Remi 80-180 RPM 1000 Ml Capacity Mini Rotary Shakers RS-12R, India) 
for 30-45 minute. ${ }^{18}$ Readings were taken at $570 \mathrm{~nm}$ in ELISA plate reader (iMark ${ }^{\mathrm{TM}}$ Microplate Absorbance Reader, BioRad, United States).

\section{SRB assay}

The SRB assay was carried out with slight modifications. ${ }^{19,20}$ Human breast cancer cells (MCF-7) were cultured in RPMI-1641 media containing 10\% FBS, $100 \mu \mathrm{g} / \mathrm{mL}$ penicillin, and $100 \mu \mathrm{g} / \mathrm{mL}$ streptomycin in a humidified atmosphere with $5 \% \mathrm{CO}_{2}$ at $37^{\circ} \mathrm{C}$. Cells were plated in $100 \mu \mathrm{L}$ of media per well (8000 cells/well) in 96 well micro titre plates. After 48 hours when the cells reached $70-80 \%$ confluence, media was removed from each well. The serum free media was added to each well after washing with PBS once and kept at $37^{\circ} \mathrm{C}$ for 12 hours. Thereafter, different dilutions of the extracts and standard drug were added in varying concentration $(10,20$, $50,100 \mu \mathrm{g} / \mathrm{mL}$ in $0.1 \% \mathrm{DMSO}$ ) to the medium. Incubation was carried out for 24 hours at $37^{\circ} \mathrm{C}$. Each well was then added with $50 \mu \mathrm{L}$ of chilled TCA (50\%) and incubated for 1 hour at $4^{\circ} \mathrm{C}$. The Solution was discarded from each well, washed with double distilled water 3- 4 times and completely air-dried at room temperature overnight. SRB $100 \mu \mathrm{L}(0.4 \%)$ was added to each well and incubated at room temperature for 30 minutes. Each well was then washed with $1 \%$ glacial acetic acid 3-4 times and completely air-dried at room temperature. Tris base solution $200 \mu \mathrm{L}$ was added to each well $(10 \mathrm{mM}, \mathrm{pH}-10.5)$. Readings were taken at $510 \mathrm{~nm}$ after 20 minutes. The standard drug taken was rapamycin at a concentration of $10 \mu \mathrm{M}$. Control group received no treatment and were supplied with culture media containing $0.1 \%$ DMSO.

The following formula was used to calculate $\%$ viability:

$$
\% \text { viability }=(\text { live cell count } / \text { total cell count }) \times 100
$$

\section{Cellular uptake study}

The cellular uptake of Aq, Eth, Halc, and rapamycin (standard drug) was studied on the MCF-7 cell lines by fluorescence method. ${ }^{21,22}$ Briefly, all the three extracts including standard drug were added to MCF-7 cell lines previously incubated with Hoechst dye $(50 \mu \mathrm{g} / \mathrm{mL})$ for half an hour separately and then were washed thrice with PBS. The cell line cultures were treated with Aq, Eth, Halc extracts, including rapamycin as a standard drug at different dilutions for different time intervals. Cells were then analyzed under a fluorescence microscope fitted with an RT spot digital camera (Nikon Eclipse E600 microscope, India). In control group, cells were incubated with the dye for 30 minutes, washed thrice with PBS and again suspended in medium and further incubated with PBS for half an hour.
Glucose concentration in the sample can be calculated using the following formula:

Glucose $=$ Absorbance of sample $/$ Absorbance of standard $\times$ Concentration of standard

\section{Intracellular glutathione assay}

Intracellular glutathione assay was carried out to estimate the reduction in intracellular glutathione level in MCF-7 cells upon exposure with Aq, Eth, and Halc extracts, including rapamycin as a standard drug at different dilutions. A commercial kit (Thiol Tracker ${ }^{\mathrm{TM}}$ Violet, Thermo Fischer, India) was used for intracellular glutathione assay. ${ }^{22,23}$ In order to quantify the intracellular glutathione levels in the cell lines and their respective controls fluorescence microplate reader (iMark ${ }^{\mathrm{TM}}$ Microplate Absorbance Reader, BioRad, United States) was employed. The study was carried out in 96 well microplates where cells were grown at a density of $1 \times 10^{5}$ cells/well in DMEM with 10\% FBS. The cells were left for attachment for 24 hours and then washed twice with fresh PBS (100 $\mu \mathrm{L} /$ well) and then exposed to Aq, Eth, Halc extracts, exposure, in the concentration range of $20-200 \mathrm{mg} / \mathrm{mL}$ supplemented with 10\% FBS. After the exposure, again the cells were washed with fresh PBS $(100 \mu \mathrm{L} /$ well $)$ and exposed to the commercial dye (Thiol Tracker ${ }^{\mathrm{TM}}$ Violet) prepared in PBS at a concentration of $20 \mu \mathrm{M}$. The incubation conditions were maintained at $37^{\circ} \mathrm{C}$ with $5 \% \mathrm{CO}_{2}$ for half an hour. The cells were washed thrice to remove the dye with $100 \mu \mathrm{l} /$ well of PBS and the cells were analyzed under the reader to measure the absorbance at $412 \mathrm{~nm}$ respectively in Bio-rad micro plate reader.

Concentration of GSH in sample $=$ Std. OD $\times$ Sample OD $\times 1000 \times$ Vol. of Supernatant/ Conc. Of Std. $\times$ $307.32 \times$ Vol. of Blood

Where $307.32=$ Molecular weight of GSH

\section{Statistical analysis}

One-Way ANOVA test (non-parametric analysis of variance) and post test Tukey Test was applied to compare all pairs of the column. Graph Pad Prism software was used for further statistical analysis.

\section{RESULTS \\ MTT assay}

The antiproliferative activity of all the three extracts viz. Eth, Aq and Halc extracts have been investigated on MCF-7 cell line at the concentration (10, 20, 50,100 $\mu \mathrm{g} / \mathrm{mL}$ in $0.1 \mathrm{DMSO}$ ) for 24, 48 and $72 \mathrm{hrs}$ (Figure 1). The hydroalcoholic extract exhibited cell viability of 


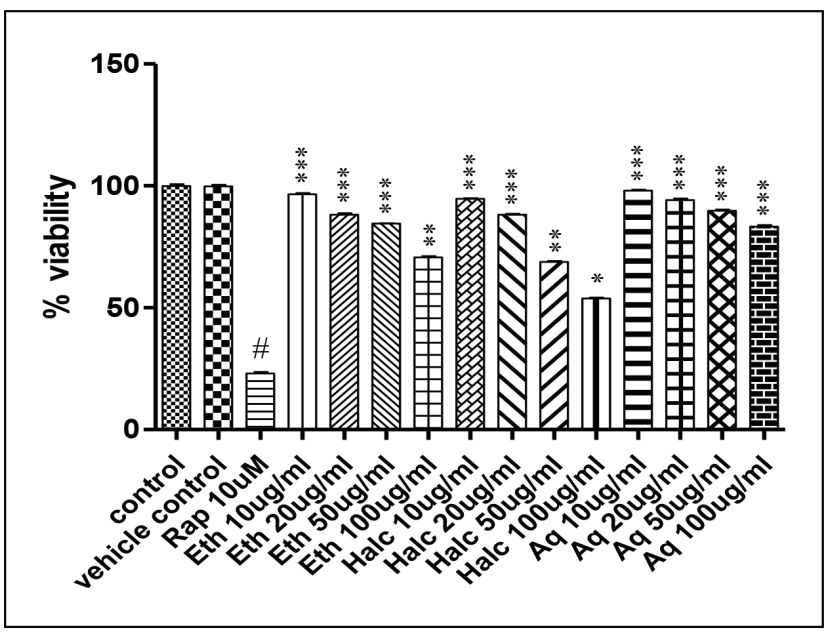

Figure 1: Measurement of cell viability using MTT assay and different extracts of Orthosiphon pallidus. Each value represents mean $\pm S E M ; n=3$. Where, $\# p<0.05$ as compared to control; ${ }^{*} p<0.05$ as compared to standard; ${ }^{* *} p<0.01$ as compared to standard; ${ }^{* * *} p<0.001$ as compared to standard.

$53.75 \pm 1.98 \%$ while ethanolic extract showed cell viability of $71.75 \pm 1.26$ and highest of $84.26 \pm 2.23 \%$ was observed in the aqueous extract at a concentration of $100 \mu \mathrm{g} / \mathrm{mL}$.

The results of MT'T assay shown the ability of cells to recover was highly significant in the aqueous extract $(\mathrm{p} \leq 0.05)$ while less in other two extracts as well as standard drug rapamycin, which shown cell viability of $23.97 \pm 1.76 \%$ suggesting high cytotoxic nature of the drug. The Aqueous extract exhibited tendency to recover the cells which are vulnerable to ROS damage also.

\section{SRB assay}

Sulforhodamine B (SRB) assay is a qualitative as well as a quantative method for confirmation of cellular toxicity in terms of protein disposition in the cell. The results of the SRB analysis had shown that the extracts exhibited significant variations in SRB values at a range from $58 \%$ to $84 \%$ in the same cell line. In terms of cytotoxicity, hydroalcoholic extracts showed an SRB value of $58.11 \pm 1.35 \%$ suggesting significant higher toxicity as compared to ethanolic extract, an aqueous extract which shown SRB value of $75.39 \pm 0.87 \%$ and $83.24 \pm 2.47 \%$ respectively. In terms of cytotoxicity, standard drug rapamycin had shown an SRB value of $28.27 \pm 2.61 \%$, resembling its MTT results (Figure 2). The results of the SRB study shown that all three extracts had cytotoxicity in an exponential order of Halc $>$ Eth $>$ Aq.

\section{In vitro cellular uptake study}

The cellular uptake affinity of Aq, Eth, and Halc extracts, including rapamycin as a standard drug on MCF-7 cell

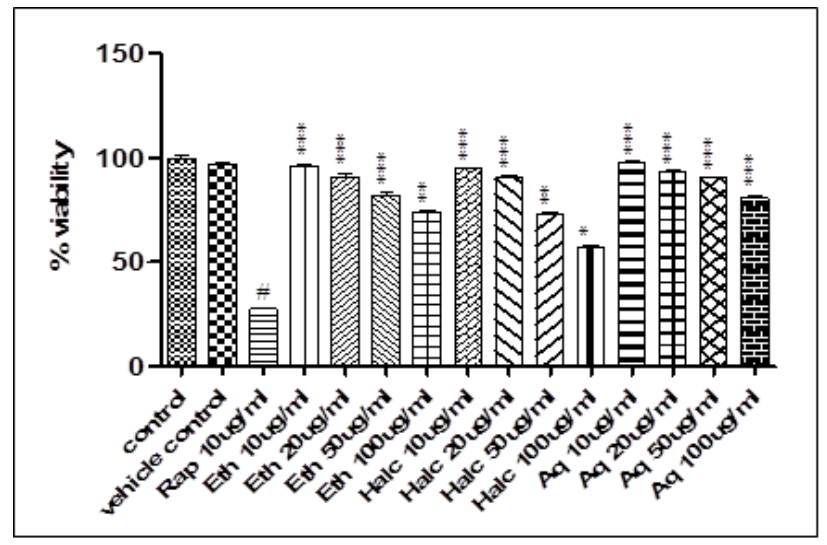

Figure 2: Measurement of cell viability in MCF cells using SRB assay for different extracts of Orthosiphon pallidus.

Each value represents mean $\pm S E M ; n=3$. Where, $\# p<0.05$

as compared to control; ${ }^{*} \mathrm{p}<0.05$ as compared to standard; ${ }^{* *} \mathrm{p}<0.01$ as compared to standard; ${ }^{* *} \mathrm{p}<0.001$ as compared to standard.

line using fluorescence microscope was also carried out to investigate cellular uptake affinity. The results of in-vitro cellular uptake of Aq, Eth, and Halc extracts were remarkably significant $(\mathrm{p}<0.05)$. The cellular uptake response of Halc was observed relatively higher than the other extracts. The response pattern was relatively similar in cells with the Aq, Eth extracts while a slightly different cellular uptake pattern was observed for the standard drug (Figure 3). Here, the cellular uptake of Halc started at an initial exposure of 5 minutes and lasted for 45 minutes. Moreover, the overall pattern cellular uptake of Aq, Eth, and Halc extracts on MCF-7 cell lines remained in an exponential order i.e. Halc > Eth $>$ Aq extracts as compared to the standard drug.

\section{Intracellular glutathione assay}

The concentration of intracellular GSH reduced significantly $(\mathrm{p}<0.05)$ when Halc was administered to the cells, in comparison to the Aq and Eth extracts (Figure 4). The rate of intracellular GSH depletion was found to be significant for Halc extract at all test concentrations of $25-150 \mu \mathrm{g} / \mathrm{L}$ in MCF-7 cell lines in 24 hours as compared to standard drug.

\section{DISCUSSION}

Breast cancer is a disorder significantly vulnerable in women across the world. In recent decades various drug therapies have been developed in order reduce the chance of occurrence of disease to lower the mortality rate due to breast cancer and to minimize the pre and post complications associated with the diseases. ${ }^{24}$ 


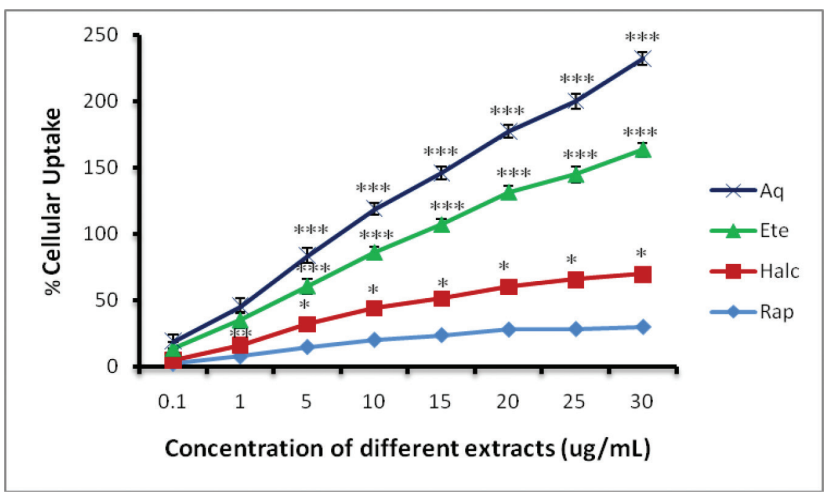

Figure 3: Measurement of in vitro cellular uptake study in MCF-7 cells by different extracts of Orthosiphon pallidus. Each value represents mean $\pm S E M ; n=3$. Where, ${ }^{*} p<0.05$ as compared to standard; ${ }^{* * *} p<0.001$ as compared to standard.

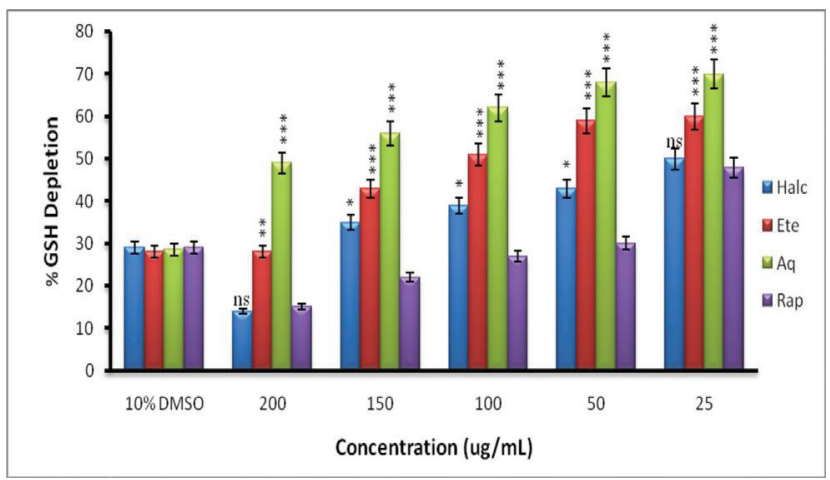

Figure 4: Measurement of \% GSH Depletion in MCF-7 cells using different extracts of Orthosiphon pallidus. Each value represents mean $\pm S E M ; n=3$. Where, $n s-p>0.05$ as compared to standard; * $p<0.05$ as compared to standard; ** $p<0.01$ as compared to standard; ${ }^{* *} p<0.001$ as compared to standard.
Graidist et.al in 2015 carried out a study in which the cytotoxicity of a crude extract of Piper cubeba was evaluated against normal fibroblast (L929), normal breast (MCF-12A) and breast cancer cell lines (MCF-7, MDA-MB-468 and MDA-MB-231). The most effective fraction was selected for DNA fragmentation assay to detect apoptotic activity. The results had shown that the methanolic crude extract had a higher cytotoxic activity against MDA-MB-468 and MCF-7 than a dichloromethane crude extract. ${ }^{25}$ Similarly, In a study conducted by Maliyakkal et.al in 2013, the cytotoxic and apoptotic effects of extracts of Withania somnifera (WS) and Tinospora cordifolia (TC) was examined on human breast cancer cells (MCF7 and MDA MB 231). A key finding was observed in the study that the extracts failed to show cytotoxicity or apoptosis in $\mathrm{HaCaT}$ cells at the concentration that was cytotoxic to breast cancer cells, indicating less cytotoxic effects of WS and TC against human 'non-cancerous' cells. ${ }^{26}$

Traditionally, there are various drugs, which claim to cure several ill-treated diseases including cancer too. Herbal drugs could be coined as an alternative to existing drug regimen for breast cancer because they are considered to have a huge plethora of active ingredients that could combat disease at multiple sites. The study was designed in such a way that the hidden potential of Orthosiphon pallidus Royle could be exploited. The plants have not been explored much for pharmacological activities till date.

In the study, different extracts (hydroalcoholic, ethanolic and aqueous) were prepared using soxhlet apparatus in varying ratio depending upon their polarity. The study is about MTT assay, SRB assay, Cellular uptake and glutathione assay using MCF-7 cell line to characterize and quantify the anticancer potential of all the extracts separately.

SRB assay and MTT assay were chosen because of their wider reliability to evaluate anticancer activity on cancer cell lines, irrespective of the nature of the test compound quality. SRB and MTT assay gives a qualitative as well as quantitative approach to evaluate the results. The results of both the assay parameters shown that hydroalcoholic extract was superior in anticancer activity when compared to ethanolic and aqueous extracts using MCF-7 cell lines. The study results were significantly closer to the study performed by Ashoken ${ }^{1}$ in which they observed the anticancer activity of aerial part of the same plant using ethanolic extract. Their study postulated that the ethanolic extract of the plant shown $51 \%$ of cytotoxicity, while in our study ethanolic extract of the plant exhibited cytotoxicity of $29-32 \%$. The hydroalcoholic extract of the plant was found more cytotoxic exerting $47-50 \%$ cytotoxicity than ethanolic as well as aqueous extract exhibiting cytotoxicity of $16 \%$. The cellular uptake response of Halc was observed relatively higher than the other extracts and similar $(\mathrm{p}<0.05)$ to a standard drug in a dose-dependent manner. The cellular uptake for Eth and Aq were revealed to show less significant changes as compared to the standard drug at all tested doses. The concentration of intracellular GSH reduced significantly $(\mathrm{p}<0.05)$ when Halc was administered to the cells, in comparison to the Aq and Eth extracts. Through literature survey it was found that minimal activity has been performed only on the ethanolic extract of the plant. So the study could be serve as a benchmark in ethnopharmacological studies 
of Orthosiphon pallidus Royle as well as the basement of scientific findings for future studies to be performed.

\section{CONCLUSION}

The ethanolic, aqueous and hydroalcoholic extracts of Orthosiphon pallidus Royle exhibited anticancer activity in a wide range in dose- dependent manner. The study conducted by Ashokan et al., showed that ethanolic extract of Orthosiphon pallidus Royle exhibited remarkable in-vitro cytotoxicity studies in tryphan blue and MTT assay at a concentration of $25 \mu \mathrm{g} / \mathrm{mL}$ with a increase of $41 \%$ of cytotoxicity. While in our observation, it was found that hydroalcoholic extract was found effective against $100 \mu \mathrm{g} / \mathrm{ml}$ for both the test (MTT and SRB), while extracts showed significant glutathione inhibition activity at a wide range (SRB value of $58 \%$ to $85 \%$ ). The cellular uptake of aqueous extract, ethanolic extract, bydroalcobolic extract, including rapamycin as standard drug, on all the MCF-7 cell lines was observed in these exponential pattern. The concentration of intracellular GSH reduced significantly $(\mathrm{p}<0.05)$ when the hydroalcoholic extract was administered to the cells, in comparison to the aqueous or ethanolic extracts. The study postulated that hydroalcoholic extract could be taken as a lead for further isolation and characterization of the compound with better therapeutic value.

\section{ACKNOWLEDGEMENT}

The authors acknowledge the Central Drug Research Laboratory, Lucknow, India for providing scientific assistance in cell line studies. One of the authors extend their gratitude towards SRIP, Kumhari, Durg, Chhattisgarh for providing facilities to carry out research work.

\section{CONFLICT OF INTEREST}

The authors declare no conflict of interest.

\section{ABBREVIATION USED}

OPRE: Orthosiphon pallidus Royle extract; MTT : [ [3-(4, 5-dimethyl thiazol-2-yl)-5-diphenyltetrazolium bromide\}]; FBS : Fetal bovine serum; PBS: Phosphate buffered saline; EDTA: Ethylenediaminetetraacetic acid; DMEM :Dulbecco's modified Eagle's medium; MEM: Minimal Essential Eagle's Medium; DMSO: Dimethyl sulfoxide; SRB: Sulforhodamine B; TCA: Trichloroacetic acid; MCF-7: Michigan Cancer Foundation-7; TPVG: Trypsin Phosphate Versene Glucose; Aq:
Aqueous extract; Eth: Ethanolic extract; Halc: Hydroalcoholic extract; Rap: Rapamycin; GSH: Glutathione

\section{REFERENCES}

1. Ashokan K, Muthuraman MS. Anticancer studies on Orthosiphon Pallidus Royle and Peristrophe bicalyculata nees. J Pharm Res. 2011;4(8):2654-6.

2. Singh MK, Gidwani B, Gupta A, Dhongade H, Kashyap PP and Tripathi DK. A Review of the Medicinal Plants of Genus Orthosiphon (Lamiaceae). Int. J. Biol. Chem. 2015;9(6):318-31. https://doi.org/10.3923/ijbc.2015.318.331.

3. Regina KMM, Adama $\mathrm{H}$, Jeanne $\mathrm{M}$, Odile $\mathrm{N}$. Ethnobotany and Ethnopharmacognosy of Lamiaceae Species from Central Burkina Faso: Leucas martinicensis (Jacquin) R. Brown, Hoslundia opposita Vahl and Orthosiphon pallidus Royle Ex Benth. American Journal of Ethnomedicine. 2015;2(4):219-32.

4. Krishnaiah D, Sarbatly R, Bono A. Phytochemical antioxidants for health and medicine- A move towards nature. Biotechnol Mol Biol Rev. 2007;2(4):97-104.

5. Prathapan A, Lijo CO, Nampoothiri SV, Mini S, Raghu KG. In vitro antiperoxidative, free radical scavenging and xanthine oxidase inhibitory potentials of ethyl acetate fraction of Saraca ashoka flowers. Nat Prod Res. 2011;25(3):298-309. https://doi.org/10.1080/14786419.2010.510472 ; PMid:21294042.

6. Kang TH, Pae HO, Yoo JC, Kim NY, Kim YC, Ko GI, et al. Antiproliferative effect of alkaloids from Sedum sarmentosum on murine and human hepatoma cell line. J Ethnopharmacol. 2000;70(2):177-182. https://doi.org/10.1016/ S0378-8741(99)00164-6.

7. Kintzios SE: Terrestrial plant derived anticancer agents and plant species used in anticancer research. Crit Rev Plant Sci. 2006;25(2):79-113. https:// doi.org/10.1080/07352680500348824.

8. Shoeb M. Anticancer agents from medicinal plants. Bangladesh J Pharmacol 2006;1(2):35-41.

9. Danhier F, Feron O, Preat V. To exploit the tumor microenvironment: passive and active tumor targeting of nanocarriers for anti-cancer drug delivery. J. Control Release 2010;148(2):135-46. https://doi.org/10.1016/j. jconrel.2010.08.027 ; PMid:20797419.

10. Rocha $A B$, Lopez RM and Schwartsmann G. Natural products in anticancer therapy. Curr. Opin. Pharmacol. 2001;1:364-99. https://doi.org/10.1016/ S1471-4892(01)00063-7.

11. Pan $\mathrm{L}$, Chai $\mathrm{H}$ and Kinghorn $\mathrm{AD}$. The continuing search for antitumor agents from higher plants. Phytochem. Lett. 2010;3(1):1-8. https://doi.org/10.1016/j. phytol.2009.11.005 ; PMid:20228943 PMCid:PMC2836022.

12. Nondo RSO, Moshi MJ, Erasto P, Zofou D, Njouendou AJ, Wanji S, et al. Evaluation of the cytotoxic activity of extracts from medicinal plants used for the treatment of malaria in Kagera and Lindi regions, Tanzania. Journal of Applied Pharmaceutical Science. 2015;5(04):007-12. https://doi.org/10.7324/ JAPS.2015.50402.

13. Cook NC, Samman S. Flavonoids-chemistry, metabolism, cardioprotective effects, and dietary sources. J Nutr Biochem. 1996;7(2):66-76. https://doi. org/10.1016/0955-2863(95)00168-9.

14. Zainol MK, Abd-Hamid A, Yusof S, Muse R. Antioxidative activity and total phenolic compounds of leaf, root and petiole of four accessions of Centella asiatica (L.) Urban. Food Chemistry. 2003;81(4):575-81. https://doi. org/10.1016/S0308-8146(02)00498-3.

15. Hakkim LF, Arivaz HG, Boopathy R. Antioxidant property of selected Ocimum species and their secondary metabolite content. J Med Plant Res. 2008;2(9):250-7.

16. Houghton P, Fang R, Techatanawat I, Steventon G, Hylands JP, Lee CC. The sulphorhodamine (SRB) assay and other approaches to testing plant extracts and derived compounds for activities related to reputed anticancer activity. Methods. 2007;42(4):377-87. https://doi.org/10.1016/j.ymeth.2007.01.003 ; PMid:17560325.

17. Patel RM, Patel SK. Cytotoxic activity of methanolic extract of Artocarpus heterophyllus against A549, Hela and MCF-7 cell lines. Journal of Applied Pharmaceutical Science. 2011;01(07):167-71.

18. Rahman S, Salehin $\mathrm{F}$ and lqbal $\mathrm{A}$. In vitro antioxidant and anticancer activity of young Zingiber officinale against human breast carcinoma cell lines. 
BMC Complementary and Alternative Medicine. 2011;11:76. https://doi. org/10.1186/1472-6882-11-76 ; PMid:21933433 PMCid:PMC3203256.

19. Mosmann T. Rapid Colorimetric Assay for Cellular Growth and Survival: Application to Proliferation and Cytotoxicity Assays. Journal of Immunology Methods. 1983;65(1-2):55-63. https://doi.org/10.1016/0022-1759(83)90303-4.

20. Skehan P, Storeng R, Scudiero D, Monks A, McMahon J, Vistica D. New Colorimetric Cytotoxicity Assay for Anticancer-Drug Screening. Journal National Cancer Institute 1990;82(13):1107-12. https://doi.org/10.1093/ jnci/82.13.1107.

21. Derakhshandeh K, Hochhaus G, Dadashzadeh S: In-vitro Cellular Uptake and Transport Study of 9-Nitrocamptothecin PLGA Nanoparticles Across Caco-2 Cell Monolayer Model. Iran J Pharm Res. 2011;10(3):425-34. PMid:24250374 PMCid:PMC3813034.

22. Gupta A, Kaur CD, Saraf S: "Skin Targeting: An approach for effective treatment in skin disorders" Lambert Academic publishing. 2016; ISBN 9783-659-88550-1.
23. Shtukmaster S, Ljubuncic $P$ and Bomzon A. The Effect of an Aqueous Extract of Teucrium polium on Glutathione Homeostasis In vitro: A Possible Mechanism of Its Hepatoprotectant Action. Advances in Pharmacological Sciences. 2010:1-7. https://doi.org/10.1155/2010/938324 ; PMid:21188245 PMCid:PMC3005810.

24. Dmitri O, Levitsky V, Dembitsky M. Anti-breast cancer agents derived from plants. Nat. Prod. Bio Prospect. 2015;5(1):1-16. https://doi.org/10.1007/ s13659-014-0048-9 ; PMid:25466288 PMCid:PMC4327996.

25. Graidist P, Martla M, Sukpondma Y. Cytotoxic Activity of Piper cubeba Extract in Breast Cancer Cell Lines. Nutrients. 2015;7(4):2707-18. https:// doi.org/10.3390/nu7042707 ; PMid:25867951 PMCid:PMC4425168.

26. Maliyakkal N, Udupa N, Pai KSR, Rangarajan A. Cytotoxic and apoptotic activities of extracts of Withania somnifera and Tinospora cordifolia in human breast cancer cells. International Journal of Applied Research in Natural Products. 2013;6(4):1-10.

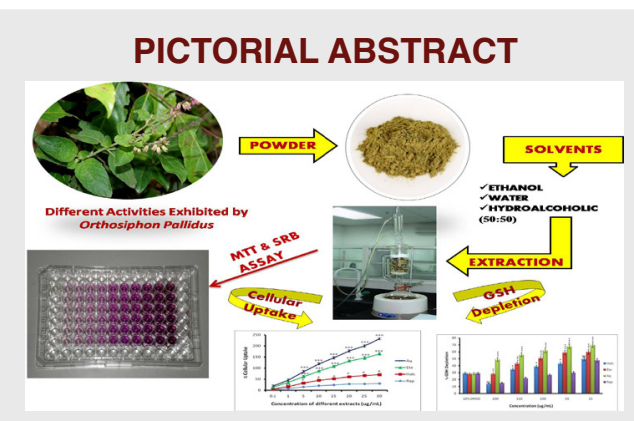

\section{SUMMARY}

- This study revealed the anticancer potential of Orthosiphon pallidus Royle in a wide range in dose-dependent manner.

Hydroalcoholic extract showed more significant activity against MCF-7 cell lines in both MTT and SRB assay.

- In Intracellular glutathione assay, the concentration was reduced significantly $(p<0.05)$ in Halc when compared with Aq and Eth extracts of Orthosiphon pallidus Royle.

- The hydroalcoholic extract of Orthosiphon pallidus Royle can be proposed to have anticancer activity in further in-vivo experimental model and can be used in near future with great success for clinical studies.

\section{About Authors}

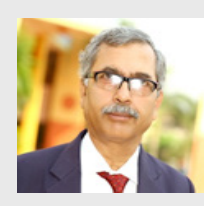

Dr. Dulal Krishna Tripathi: He is Professor \& Principal in the Rungta College of Pharmaceutical Science and Research, Kohka - Kurud Road, Bhilai, Chhattisgarh. He is having more than 38 years (Industry, Administration and Academic \& research) experience and presently Dean of Faculty of Pharmacy, Chhattisgarh Swami Vivekanand Technical University Bhilai, C.G. He is a member of a number of professional and scientific societies as well as serving the position of reviewer and editorial board member of various international journals. He has published more than 100 research and review articles in various reputed journals and also authored three book (Industrial Pharmacy, ISBN 978-93-83635-59-7, Pharmaceutics ISBN: 978-93-5230-156-0, Elementary Pharmaceutical Calculations, ISBN: 978-93-5230-157-7) PharmaMed Press (A Unit of BSP Books Pvt. Ltd.), Hyderabad.

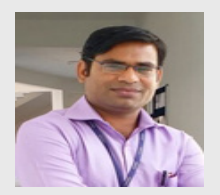

Dr. Hemant Dhongade: He is Associate Professor Shri Rawatpura Sarkar Institute of Pharmacy, Kumhari, Durg, and Chhattisgarh, India. He has more than 40 research \& review publications in national and international journals. He also presented 25 research outcomes at several national and international platforms.

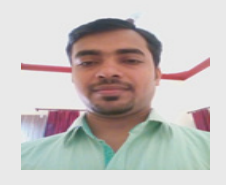

Mr. Mukesh K. Singh: He is working as Assistant Professor at Shri Rawatpura Sarkar Institute of Pharmacy, Kumhari, Durg, and Chhattisgarh, India. He had completed B. Pharm from LNCP Bhopal in 2007 and M. Pharm from SRM University, Chennai in 2009. He is pursuing PhD in Pharmaceutical Sciences from Chhattisgarh Swami Vivekanand Technical University Bhilai, C.G. He has more than 30 research \& review publications in national and international journals. He had presented 20 research outcomes at several national and international platforms.

Cite this article: Singh MK, Dhongade H, and Tripathi DK. Comparative Evaluation of in vitro Cellular Uptake and Antiproliferative Potential of Different Extracts of Orthosiphon pallidus Royle. Indian J of Pharmaceutical Education and Research. 2017;51(4):722-8. 